\title{
Spatial variation in coral reef fish and benthic communities in the central Saudi Arabian Red Sea
}

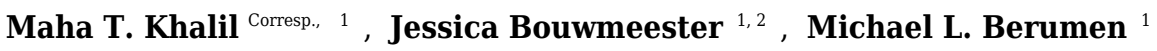 \\ 1 Red Sea Research Center, Division of Biological and Environmental Science and Engineering, King Abdullah University of Science and Technology, \\ Thuwal, Saudi Arabia \\ 2 Department of Biological and Environmental Sciences, College of Arts and Sciences, Qatar University, Doha, Qatar \\ Corresponding Author: Maha T. Khalil \\ Email address: maha.khalil@kaust.edu.sa
}

Local-scale, ecological information is critical as a sound basis for spatial management and conservation and as support for ongoing research in relatively unstudied areas. We conducted visual surveys of fish and benthic communities on 9 reefs ( $3-24 \mathrm{~km}$ from shore) in the Thuwal area of the central Saudi Arabian Red Sea. Fish biomass increased with increasing distance from shore, but was generally low compared to reefs experiencing minimal human influence around the world. All reefs had a herbivore-dominated trophic structure and few top predators, such as sharks, jacks, or large groupers. Coral cover was considerably lower on inshore reefs, likely due to a 2010 bleaching event. Community analyses showed inshore reefs to be characterized by turf algae, slower-growing corals, lower herbivore diversity, and highly abundant turf-farming damselfishes. Offshore reefs had more planktivorous fishes, a more diverse herbivore assemblage, and faster-growing corals. All reefs appear to be impacted by overfishing, and inshore reefs seem more vulnerable to thermal bleaching. The study provides a description of the spatial variation in biomass and community structure in the central Saudi Arabian Red Sea and provides a basis for spatial prioritization and subsequent marine protected area design in Thuwal. 
1 Spatial variation in coral reef fish and benthic communities in the 2 central Saudi Arabian Red Sea

3 Maha T. Khali1 ${ }^{\mathrm{a}}$; Jessica Bouwmeester ${ }^{\mathrm{ab}}$; and Michael L. Berumen ${ }^{\mathrm{a}}$

4 aRed Sea Research Center, Division of Biological and Environmental Science and Engineering,

5 King Abdullah University of Science and Technology, Thuwal, 23955-6900, Saudi Arabia

$6{ }^{\mathrm{b}}$ Department of Biological and Environmental Sciences, College of Arts and Sciences, Qatar

7 University, Doha, Qatar

8 Authors' Contact Information:

9 *Corresponding author: Maha T. Khalil: maha.khalil@kaust.edu.sa, Tel: +20 1023405556

10 Jessica Bouwmeester: jessica@qu.edu.qa

11 Michael L. Berumen: michael.berumen@kaust.edu.sa 


\section{Abstract}

13 Local-scale, ecological information is critical as a sound basis for spatial management and

14 conservation and as support for ongoing research in relatively unstudied areas. We conducted

15 visual surveys of fish and benthic communities on 9 reefs $(3-24 \mathrm{~km}$ from shore) in the Thuwal

16 area of the central Saudi Arabian Red Sea. Fish biomass increased with increasing distance from

17 shore, but was generally low compared to reefs experiencing minimal human influence around

18 the world. All reefs had a herbivore-dominated trophic structure and few top predators, such as

19 sharks, jacks, or large groupers. Coral cover was considerably lower on inshore reefs, likely due

20 to a 2010 bleaching event. Community analyses showed inshore reefs to be characterized by turf

21 algae, slower-growing corals, lower herbivore diversity, and highly abundant turf-farming

22 damselfishes. Offshore reefs had more planktivorous fishes, a more diverse herbivore

23 assemblage, and faster-growing corals. All reefs appear to be impacted by overfishing, and

24 inshore reefs seem more vulnerable to thermal bleaching. The study provides a description of the

25 spatial variation in biomass and community structure in the central Saudi Arabian Red Sea and

26 provides a basis for spatial prioritization and subsequent marine protected area design in Thuwal. 


\section{Introduction}

Despite the uniqueness of its environment and the fact that it possesses one of the longest coral reef systems in the world, coral reef ecology remains relatively understudied in the Red Sea in comparison to other biogeographical regions (Berumen et al. 2013). Detailed information on spatial patterns of fish biomass, fish densities, and structure of benthic and fish assemblages are available only for some parts of the Red Sea, primarily the Gulf of Aqaba and parts of Egypt (e.g., Bouchon-Navaro and Bouchon 1989; Alwany and Stachowitsch 2007).

Saudi Arabia has the largest stretch of Red Sea coastline (approximately $1700 \mathrm{~km}$ ) and is home to a variety of coral reef habitat types (e.g., Sheppard et al. 1992), yet there are relatively few accessible publications available from this region that report basic and detailed ecological patterns. Ecological information from the Saudi Arabian Red Sea is mostly confined either to reports prepared by collaborating regional and international organizations and published in grey literature (e.g., PERSGA/GEF 2003) or to large-scale studies focused on regional trends and patterns (e.g., Roberts et al. 1992; Price et al. 1998; DeVantier et al. 2000; Roberts et al. 2016). With the exception of a few recent studies (e.g., Furby et al. 2013), little work has been done to characterize reef communities on small, local scales, which are appropriate for informing local resource-managers and decision makers (Margules and Pressey 2000), and there are even fewer studies using detailed taxonomic resolution (e.g., fish or benthic species).

However, recent expansion of research activity in Saudi Arabia (Mervis 2009) has begun to address questions about the functioning of Red Sea reefs at local scales (e.g., Davis et al. 2011; Jessen et al. 2013; van der Merwe et al. 2014). One example is the thermal bleaching event that occurred in summer 2010 (Furby et al. 2013, Pineda et al. 2013), which raised questions about the potential local impact of overfishing and coastal development on the inherent ability of reefs to recover from such major disturbances (resilience), particularly in the presence of climate change (Khalil et al. 2013). Ongoing research efforts and eventual conservation planning increasingly highlight the need for detailed assessments of local and regional (e.g., Roberts et al. 2016) reef communities.

This study aimed to describe the reef communities off the coast of Thuwal in the central Saudi Arabian Red Sea by exploring spatial patterns of the biomass, density, and diversity of reef fishes at two different depths, with focus on important trophic and commercial groups. We also describe the cross-shelf and vertical spatial variation in benthic cover and in fish and benthic assemblages. We expected to find a cross-shelf gradient of increasing overall fish biomass and diversity with distance from shore due to typical environmental gradients in reef topography, bathymetry, sedimentation, food availability, or human impact, which are recurring patterns found in previously conducted cross-shelf analyses around the world (e.g., Fabricius 2005; Aguilar-Perera and Appeldoorn 2008; Nemth and Appeldoorn 2009; Malcolm et al. 2010). We also expected to find clear spatial variation in fish species richness and assemblage co-occurring with any differences in benthic assemblage (Roberts and Ormond 1987; Chabanet et al. 1997; 
65

66

67

68

69

70

71

72

73

74

75

76

77

78

Chong-Seng et al. 2012). Finally, we suggest potential explanations and implications of some of these spatial patterns based on comparisons to other parts of the world. The ultimate aim of the study was to provide a scientific basis for subsequent spatial prioritization and conservation planning (see Khalil 2015) by highlighting local areas of high and low diversity or biomass.

\section{Methods}

\subsection{Study Site}

The study area includes 355 patch reefs of varying sizes distributed within an area of about 2200 $\mathrm{km}^{2}$ along approximately $70 \mathrm{~km}$ of the central Saudi Arabian coast. The furthest reef is about 25 $\mathrm{km}$ from shore. The coastline in this area is moderately developed, with two relatively large coastal towns and one small fishing town called Thuwal $\left(22.28^{\circ} \mathrm{N}, 39.10^{\circ} \mathrm{E}\right)$ (Figure 1). The area suffered from a severe bleaching event in the boreal summer of 2010, which had the highest impact on reefs closest to shore. Inshore reefs lost most of their adult coral cover up to a depth of 10 meters and experienced a change in coral assemblage (Furby et al. 2013).

We surveyed 9 reefs at various distances from shore (Figure 1). The three offshore reefs (furthest from shore and adjacent to waters deeper than $200 \mathrm{~m}$ ) were, from north to south, Abu Romah Reef (RR), Nazar Reef (NR), and Abu Madafi Reef (AMR). Midshelf reefs (closer to shore and adjacent to waters that are 50-200 m deep) were Al-Fahal Reef (FR), Al-Taweel Reef (TWR), and Abu-Henshan Reef (AHR). Inshore reefs (closest to shore and surrounded by waters around $20 \mathrm{~m}$ deep) were Abu Shosha Reef (ASR), Tahla Reef (TR), and East Fsar Reef (EFR). Typical of the region, these reefs are arranged in small clusters, with relatively large elongated reef patches oriented on a north-south axis and surrounded by smaller, rounder, patches and pinnacles. All study reefs have relatively steep walls dropping down to $20 \mathrm{~m}$ or deeper and very shallow reef tops, with the exception of inshore reefs which drop to a sloping seabed at $10-15$ m (Sheppard et al. 1992). 


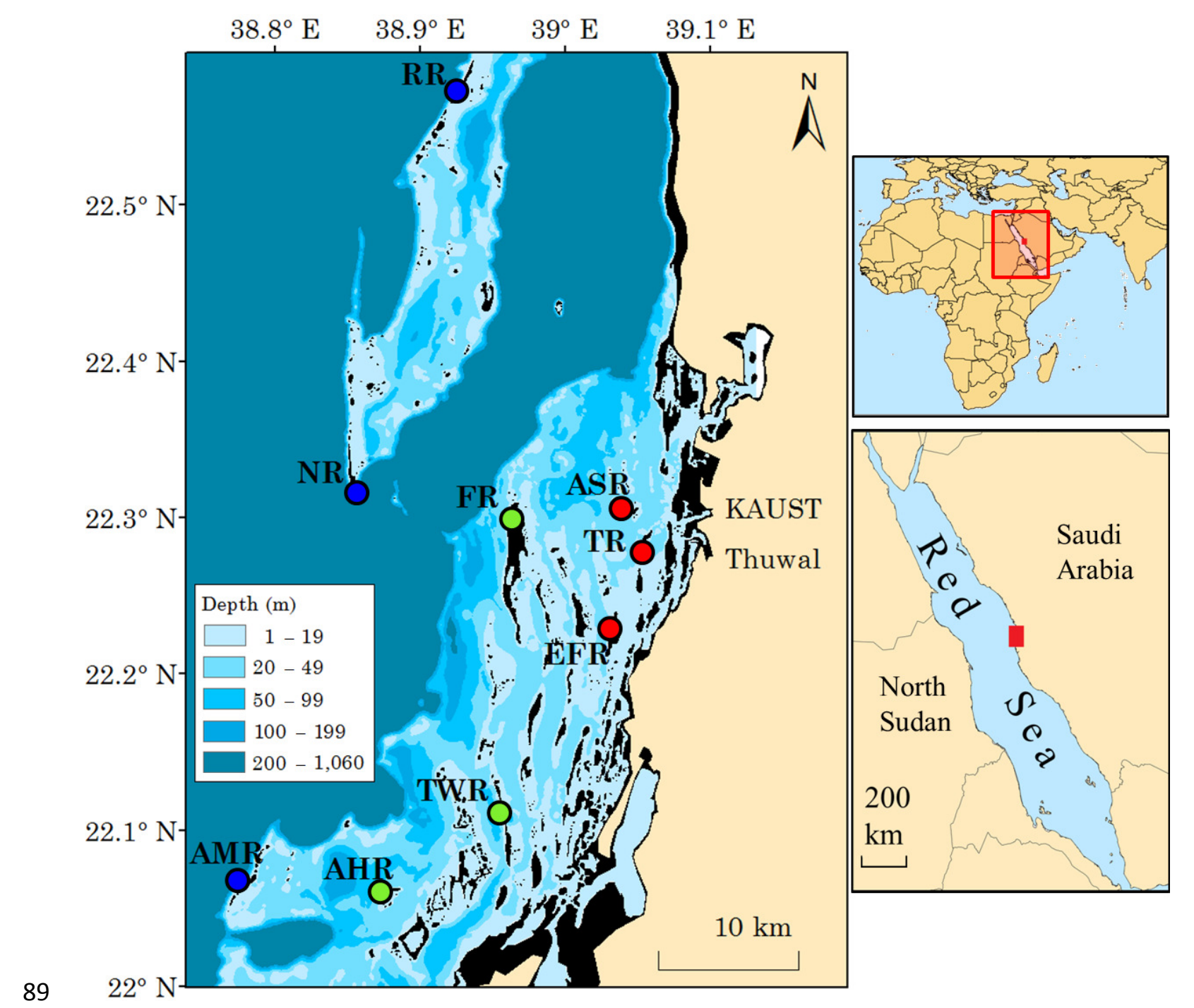

Figure 1. The study area and locations of surveyed reefs in the central Saudi Arabian Red Sea (left-hand panel). Depth is color-coded as noted in the inset key. The black color represents the shallowest portion of reef areas (seasonally intertidal). Reef name abbreviations (see main text) are shown next to their respective, color-coded marker circles: red $=$ inshore reefs; green $=$ midshelf reefs; blue $=$ offshore reefs. GPS coordinates are indicated by a decimal-degree grid on the left and top margins.Right-hand panels show the georgraphic location of the Red Sea and the location of the study site along its coast. (Map created in ArcMap, version 10.1, by MTK using various mapping sources freely available on the web through ESRI ${ }^{2}$.)

\subsection{Fish and Benthic Surveys}

Surveys were conducted in May 2013 at two depths (on the reef wall at $10 \mathrm{~m}$ and on the reef crest at $1-3 \mathrm{~m}$ ) at each of the 9 reefs. On the inshore reefs, the deep transects at $10 \mathrm{~m}$ were at the bottom where the reef walls sloped to meet the sandy sea floor. All transects were located on the west sides of the reefs, exposed to prevailing winds, currents, and waves. Fish surveys were conducted along three belt transects at each depth (a total of 6 transects per reef), where a diver swam along the transects twice, first to record larger vagile fish $(>18 \mathrm{~cm}$ TL) in $25 \times 8 \mathrm{~m}$ belts and a second time to record smaller fish $(<18 \mathrm{~cm} \mathrm{TL})$ in $25 \times 4 \mathrm{~m}$ belts (following Sandin et al. 
105

106

107

108

109

110

111

112

113

114

115

116

117

118

119

120

121

122

123

2008). Individual fishes were counted and their sizes were estimated and placed in categories of total length in $\mathrm{cm}(0-3,4-5,6-10,11-15,16-20 \ldots 61-70,71-80 \ldots 101-150,151-$ $200 \mathrm{~cm}$ ). Categories larger than $100 \mathrm{~cm}$ were merged as only two species (the moray eel Gymnothorax javanicus and the white tip reef shark Triaenodon obesus) were observed in these categories, and we were less confident in the accuracy of these size estimates. We did not attempt to count cryptic species (see Table S1 for a list of species observed) as these are poorly described in the Red Sea and require specific sampling methods (e.g., Tornabene et al. 2012).

Benthic surveys to determine live scleractinian (hard) coral cover, coral genus richness, and other benthic categories were conducted on the same transects as the fish surveys using the lineintercept method. Apart from hard coral genera, we recorded the cover of soft corals and zoanthids (to genus level when possible), sponges, crustose coralline algae (CCA), turf algae, and "other" algae. Transects for benthic surveys were $10 \mathrm{~m}$ long and located in the middle of each of the $25 \mathrm{~m}$ transects used for counting fish, making a total of 6 transects per reef, 3 at each depth. The transect length was chosen for its convenience in the field, to be comparable to previous studies done in this region (Furby et al. 2013), and because it has been previously shown to be adequate for quantitative studies of coral cover (Beenaerts and Berghe 2005). In order to minimize the impact of observer bias, all data were collected by the same divers (JB benthos, MLB fishes).

\subsection{Biomass, Abundance, and Diversity Estimations}

\subsubsection{Fish Biomass and Trophic Composition}

Fish biomass was calculated following Friedlander and DeMartini (2002) using the equation: $W=a \times L^{b}$, where $W$ is the weight of the fish in grams, $L$ is its total length (TL) in cm and $a$ and $b$ are species-specific constants obtained from FishBase (2014) (see Table S1 for a list of species-specific constants). For the $L$ value, we used the mid-range value of each TL size category. When several values of $a$ and $b$ were present in the database for a given species, we used an average of the available values, and when values were missing from the database, we used those provided for sister species, the genus, or the family. The average biomass of all species was then calculated in $\mathrm{kg} / 100 \mathrm{~m}^{2}$ for each reef, and, from these values, we summarized the biomass of four trophic guilds (top predators, carnivores, herbivores, and planktivores) and 3 major groups of commercially targeted fish, which included 25 species in 5 subfamilies: parrotfishes (Scarinae and Sparisomatinae: 10 species), snappers (Lutjaninae: 6 species), and groupers (Serraninae and Epinephelinae: 9 species) (Table S2). Trophic guilds were assigned following Sandin et al. (2008).

\subsubsection{Fish and Coral Diversity}

The total number of fish species (species richness) per reef was determined (i.e., if an individual was recorded on any one of the six transects per reef). Species richness was then used to calculate Shannon's Diversity Index $(H)$, which was in turn used to calculate species evenness 
142 using the equations: $H_{(R)}=-\sum_{i=1}^{S}\left(P_{(i)} x \ln P_{(i)}\right)$ and $E_{(R)}=H_{(R)} / \ln S$, where $H_{(R)}$ is Shannon's

143 Diversity Index for a reef $R$, which has $1 \rightarrow S$ number of species (thus, $S$ is species richness), $P$ is

144 the proportion of species $i$ (number of individuals of the species/total number of individuals of

145 all species), and $E_{(R)}$ is species evenness for reef $R$ (Heip et al. 1998). For scleractinian corals,

146 genus richness, which has been shown to be an adequate surrogate for species richness

147 (Balmford et al. 1996; Bett and Narayanaswamy 2013), was recorded on each reef. Species

148 richness was not measured directly for the sake of convenience in the field and due to the high

149 probability of identification errors encountered within many genera present in the Red Sea.

150 Several recent studies in the region have revealed troublesome scleractinian groups and new

151 taxonomic discoveries (e.g., Huang et al. 2014; Terraneo et al. 2014; Arrigoni et al. 2015;

152 Bouwmeester et al. 2015), highlighting the need for caution when working at the species level in 153 this region until coral taxonomy is formally revised.

154

155

156

157

158

159

160

161

162

163

164

165

166

167

168

169

170

171

172

173

174

175

176

\subsection{Spatial Trends and Statistical Analysis}

In order to explore potential spatial variation in overall fish biomass, commercial fish biomass, and overall species richness, we used Kruskal-Wallis tests (KW) with post-hoc Mann-Whitney U tests (MW) to identify significant differences between the medians of the samples for all reefs. These non-parametric tests were chosen due to deviations from normality that occurred in the data collected from some of the reefs. However, for fish species richness, one-way ANOVA and post-hoc Tukey's tests were used to compare the means of the reefs, since richness datasets successfully met assumptions of normality. Pearson's correlation tests were used to explore potential correlations between distance from shore and overall biomass at both sampled depths as well as to explore correlations between coral cover or coral genus richness and fish biomass or fish species richness. SPSS Statistics ${ }^{\circledR}$, version 21 , was used to conduct these statistical analyses.

\subsection{Fish and Benthic Assemblages}

In order to identify and analyze patterns of similarity in assemblages across reefs, we created non-metric multidimensional scaling (NMDS) plots using fish biomass, fish densities, and benthic cover data. All data were $\log$-transformed $(\log (\mathrm{x}+1))$ to eliminate biases caused by very highly abundant species, and the Bray-Curtis method was used to create all resemblance matrices. As per guidelines provided by Clarke (1993) for ecological data, we considered plots with $2 \mathrm{D}$ stress values higher than 0.2 to be poor representations of the data in 2-dimensional space, while stress values lower than 0.1 to be excellent representations. Most analyses were followed up by analyses of similarity (ANOSIM) to test for significant clustering and similarity percentage (SIMPER) analyses to identify the top species or categories contributing to dissimilarity between clusters (Clarke 1993). The software PRIMER, version 6, was used for these analyses (Clarke and Gorley 2006). 
177

178

179

180

181

182

183

184

185

186

187

188

189

190

191

192

193

194

195

3. Results

\subsection{Fish biomass increased moderately with distance from shore, and trophic composition was dominated by herbivores.}

A grand total of 13,792 fishes from 136 species and 44 families/sub-families (Table S1) were counted on the surveys. Overall, fish biomass was higher at $2 \mathrm{~m}$ depth than at $10 \mathrm{~m}$ on most reefs (Figures 2 and 3; see Table S3 for a summary of exact values). However, mean fish biomass at $10 \mathrm{~m}$ significantly positively correlated with distance from shore (Pearson's test, $r=0.881, R^{2}=$ $0.800, p=0.002$ ), while at $2 \mathrm{~m}$ it did not (Figure $2 \mathrm{~b}$ ). The grand mean of fish biomass for all Thuwal reefs, with depths pooled, is $16.4 \mathrm{~kg} / 100 \mathrm{~m}^{2}$.

Biomass trophic composition on all reefs was dominated by herbivores at both depths with few to no top predators, with the exception of one offshore reef (NR), which was the only reef in which top predator biomass was dominant at $10 \mathrm{~m}$ (Figure 3). This was due to the observation of two whitetip reef sharks (Triaenodon obesus) on one of the $10 \mathrm{~m}$ transects on that reef. No sharks were observed on any of the other reefs. Other observed fish that were considered top predators were grouper, snapper, eel, and jack species. The biomass of herbivores correlated significantly with distance from shore at $10 \mathrm{~m}$ (Pearson's test, $r=0.811, R^{2}=0.657, p=0.008$ ), but not at $2 \mathrm{~m}$ (Pearson's test, $r=0.487, R^{2}=0.238, p=0.183$ ). The grand mean biomass of trophic groups on Thuwal reefs is $1.0 \pm 0.2,10.8 \pm 2.6,2.5 \pm 0.1$, and $2.1 \pm 1.2 \mathrm{~kg} / 100 \mathrm{~m}^{2}$ for planktivores, herbivores, carnivores, and top predators, respectively. 
(a)

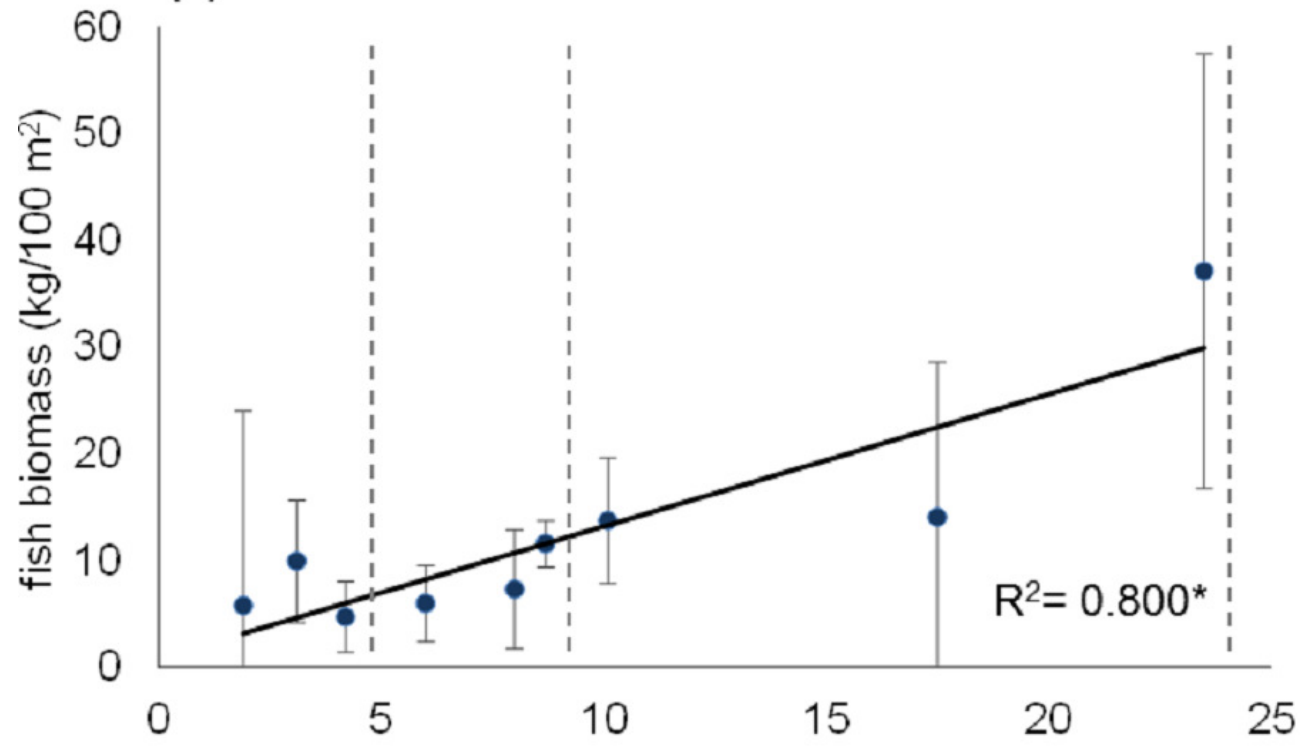

(b)

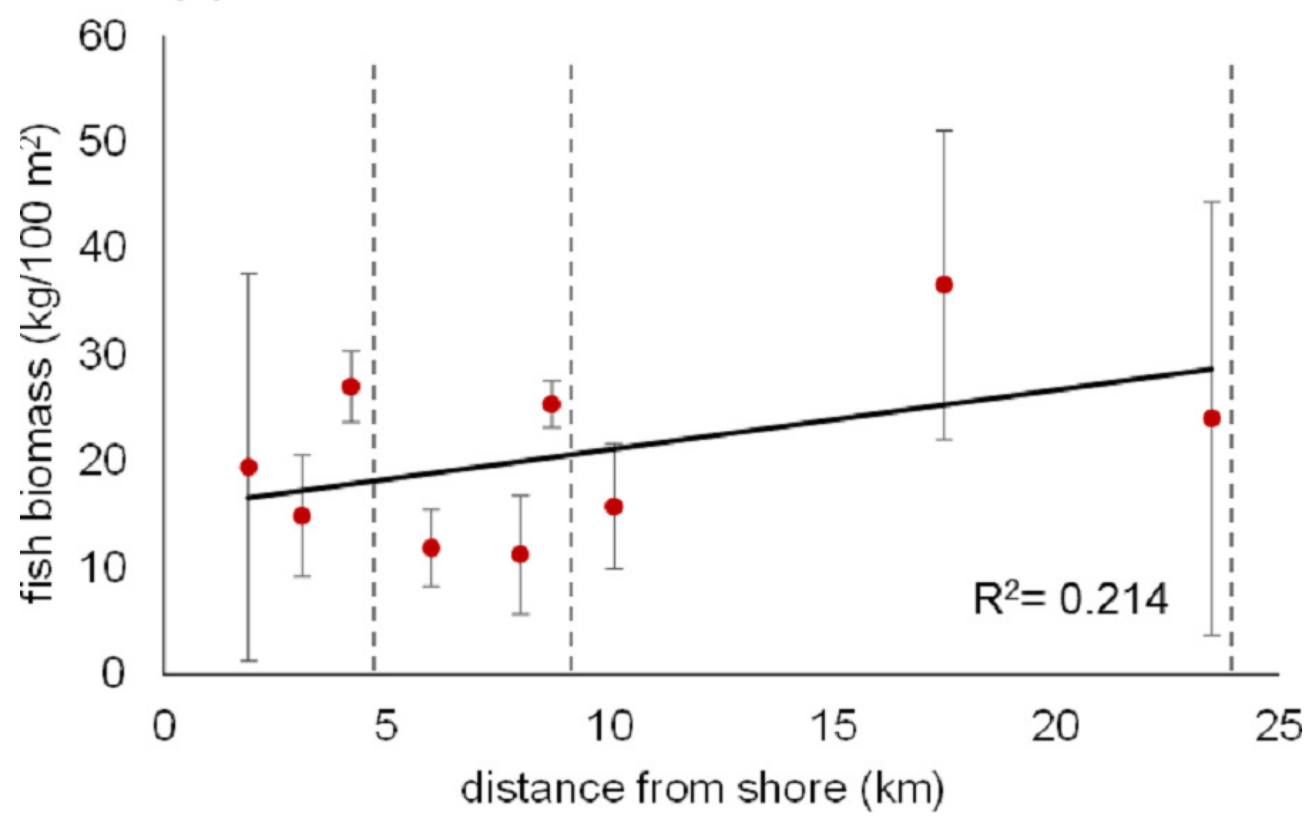

Figure 2. Mean fish biomass in $\mathrm{kg} / 100 \mathrm{~m}^{2}$ at (a) $10 \mathrm{~m}$ and (b) $2 \mathrm{~m}$ plotted against nearest straight line distance from shore as calculated in ArcMap. Error bars represent standard error. $\mathrm{R}^{2}$ values are shown on each panel and suggest strong correlation at $10 \mathrm{~m}$ and poor correlation at $2 \mathrm{~m} ;\left(^{*}\right)$ indicates significant correlation (Pearson's test, $\mathrm{p}=$ 0.002). Dotted vertical lines delimit inshore, midshelf, and offshore areas. Fish surveys were conducted in May 2013 on 9 reefs in the central Saudi Arabian Red Sea, with 3 replicate $25 \times 8$ m belt transects at each depth per reef. 
(a)

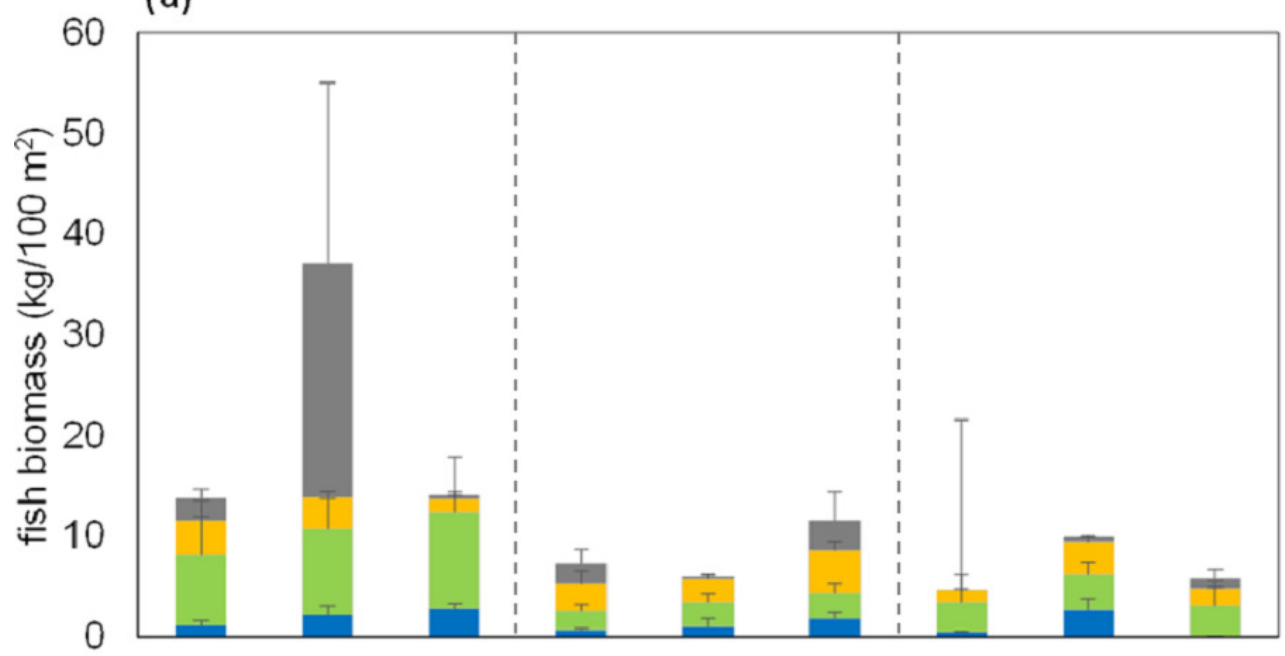

(b)

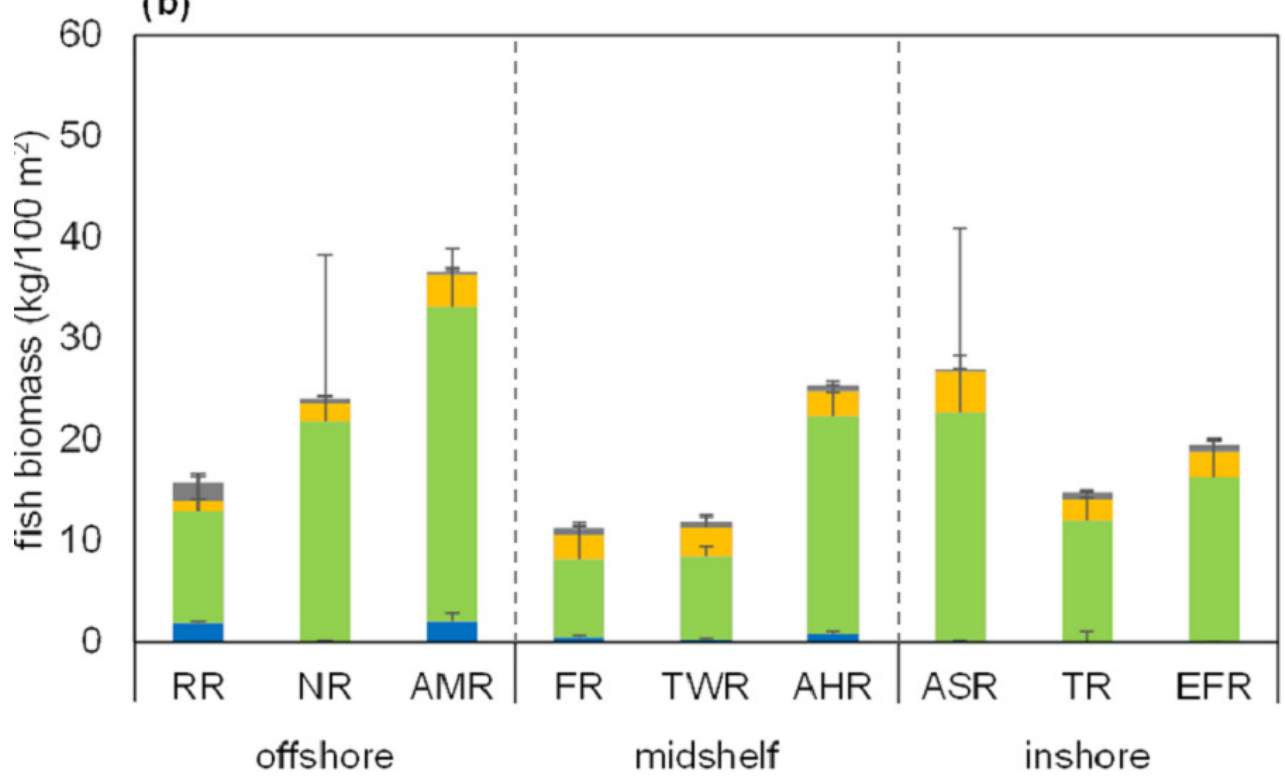

mplanktivores $\square$ herbivores $\|$ carnivores $\|$ top predators

Figure 3. Mean fish biomass in $\mathrm{kg} / 100 \mathrm{~m}^{2}$ for each of the 9 study reefs at (a) $10 \mathrm{~m}$, and (b) $2 \mathrm{~m}$ depth, color-coded according to stacked trophic group as per the inset key (planktivores, herbivores, carnivores, or top predators). Error bars show standard errors (SE) of the means. Means and SE bars shown are not relevant to the non-parametric tests described in the main text, but are shown to facilitate comparisons with other studies. Reef name abbreviations are presented on the x-axis (see main text for full names) and separated according to distance from shore into offshore, midshelf, and inshore reefs (delimited by vertical dotted lines for easy visualization). All data were collected in May 2013 from the central Saudi Arabian Red Sea.

\subsection{Commercial fish biomass did not differ significantly between reefs.}

Offshore reefs collectively had the highest mean biomass of the three commercial fish groups surveyed (see Table S2 for a list of commercial fish species), while inshore reefs had the lowest (Figure 4). However, these differences were not statistically significant. There were also no significant differences between individual reefs (KW, $p>0.05$ for all comparisons). For a 
215 complete list of commercial fish species observed in each group and for biomass values on 216 individual reefs, please refer to Tables S2 and S3.

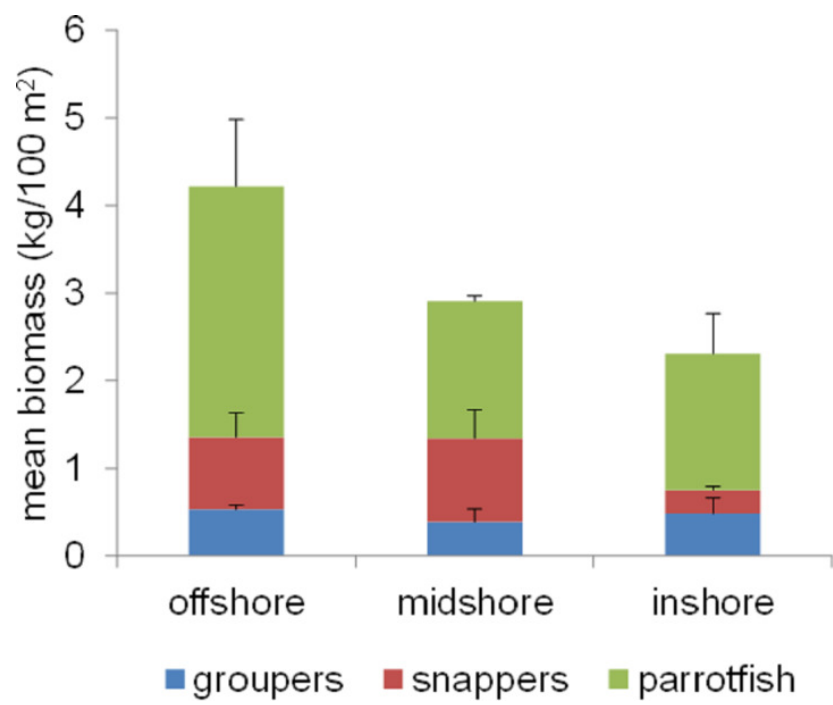

Figure 4. Mean biomass of the 3 most targeted commercial fish groups in Saudi Arabia: parrotfish, snappers, and groupers, color-coded as indicated by the inset key and averaged across 3 offshore, 3 midshelf, and 3 inshore reefs in the central Saudi Arabian Red Sea. Bars represent standard error (SE). Means and SE bars shown are not relevant to the non-parametric tests described in the main text, but are shown to facilitate comparisons with other studies.

3.3. Coral cover was significantly lower on inshore reefs, and algal cover decreased moderately with distance from shore.

We recorded a total of 38 benthic categories, including 25 genera of scleractinian corals (listed in Table S4). Mean percent coral cover ranged from $8.35 \%( \pm 3.3)$ on inshore reef ASR to $30.70 \%$ $( \pm 3.7)$ on midshelf reef TWR (Figure 5; Table S4 for a summary of exact values). There was no strong correlation between coral cover and distance from shore (Pearson's test, $r=0.470, R^{2}=$ $0.221, p=0.202)$. However, one-way ANOVA tests showed significant difference between individual reefs $\left(F=16.7, p=3 \times 10^{-6}\right)$, and post-hoc tests showed that coral cover on inshore reefs was significantly lower than that of midshelf reefs $\left(p_{\text {Tukey }}=2 \times 10^{-5}\right)$ and offshore reefs $\left(p_{\text {Tukey }}=7 \times 10^{-6}\right)$. Coral cover also did not correlate strongly with fish species richness or with fish biomass (Pearson's tests, $p=0.738$ and 0.714 , respectively). As for mean algal cover, there was a moderate negative correlation with distance from shore (Pearson's test, $r=-0.658, R^{2}=$ $0.433, p=0.054$ ), which co-occurred with the aforementioned positive correlation of herbivorous fish biomass with distance from shore. 
(a)

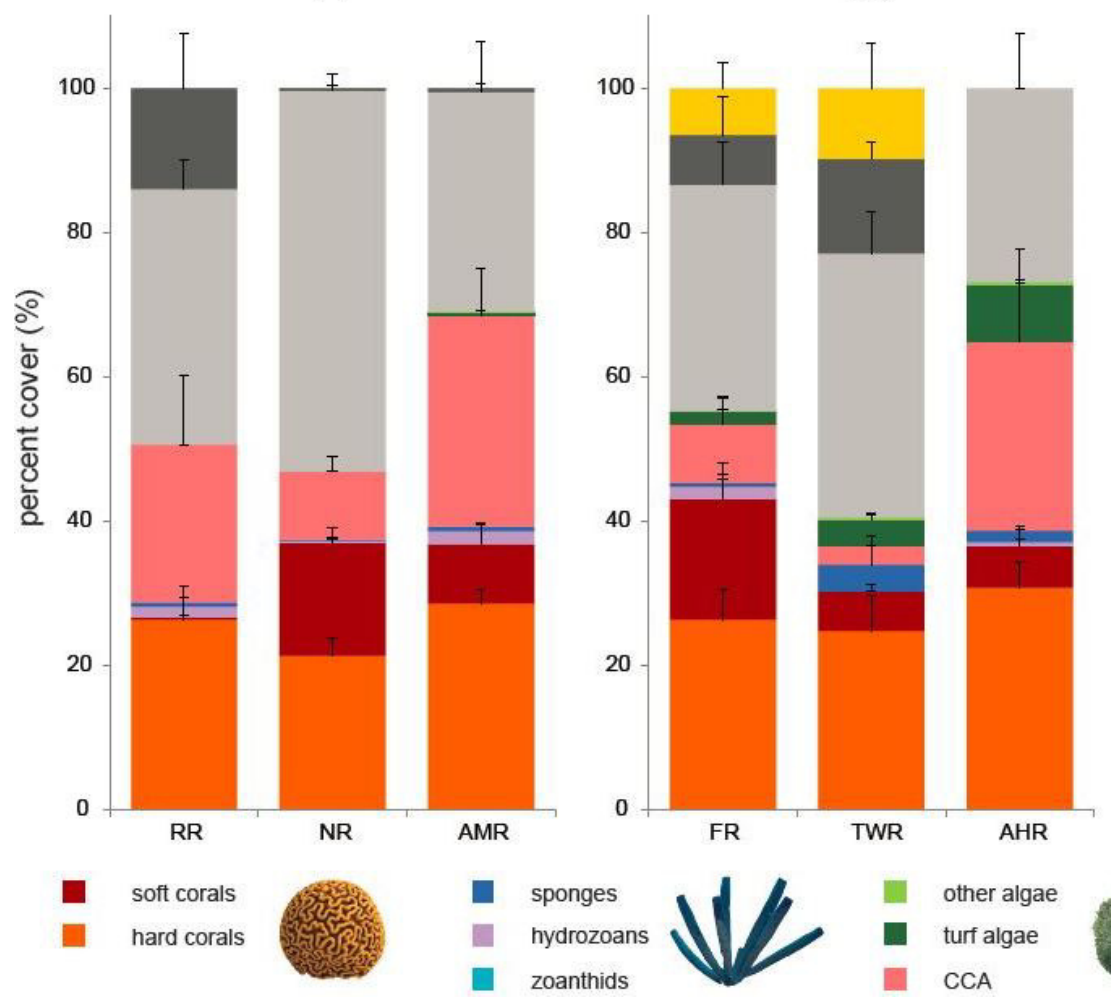

(b)

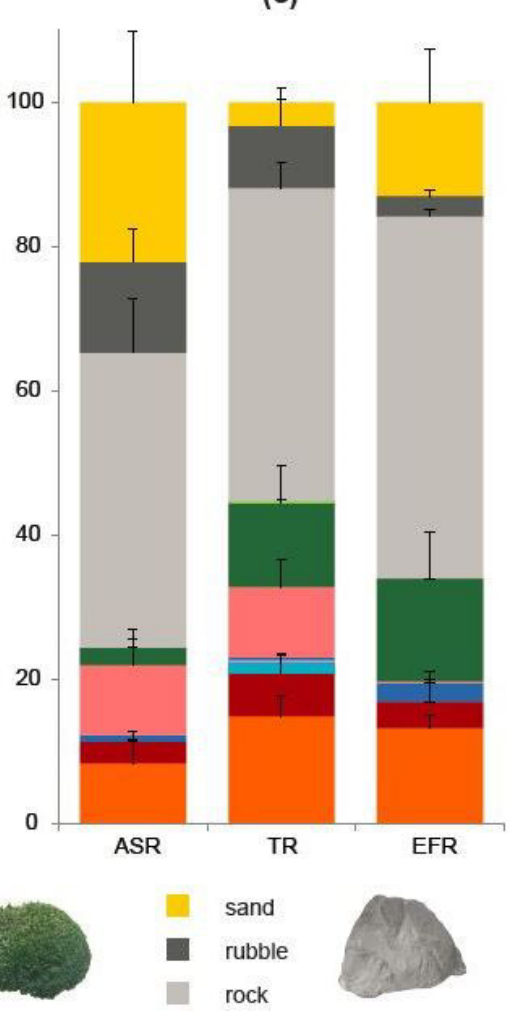

237

238

239

240

241

242

243

Figure 5. Mean percent cover ( $\pm \mathrm{SE}$ ) of benthic categories recorded on (a) 3 offsure, (b) 3 midshelf, and (c) 3 inshore reefs in the central Saudi Arabian Red Sea. Reef names are shown as abbreviations on the x-axes and separated according to distance from shore (full names in Section 2.1). Data were collected from three $10 \mathrm{~m}$ long transects at $10 \mathrm{~m}$ and three at $2 \mathrm{~m}$ depth using the line-intercept method. The category Hard corals summarizes values for 25 scleractinian coral genera that were observed (listed in table S4); Soft corals summarize at least 6 genera; Hydrozoans contained only the genus Millepora; Zoanthids only contained the genus Palythoa, and the remaining categories are listed in the legend. CCA: crustose coralline algae.

\subsection{Richness and diversity indices did not differ significantly between reefs.}

A total of 136 species of fish were recorded in our surveys (Table S1). Fish species richness ranged from 54 on one of the inshore reefs (ASR) to 70 species on one inshore reef (TR) and one midshelf reef (TWR). Species evenness, which was calculated from Shannon's Index for each reef, ranged narrowly from 0.59 to 0.77 , indicating a fairly even number of individuals per species on all reefs (Table 1). Species richness was highest on average on midshelf reefs, but no statistical significance was found (one-way ANOVA, $F=2.461, p=0.166$ ).

A midshelf reef (FR) had the highest number of hard coral genera (23), while an inshore reef (ASR) had the lowest (10 genera). MW tests showed inshore reef ASR to have significantly lower coral genus richness than all but two other reefs $\left(p_{\mathrm{MW}}<0.005\right)$. Coral genus richness also had a poor linear correlation with fish species richness (Pearson's test, $r=0.224, R^{2}=0.050, p=$ 0.562 ) and fish biomass (Pearson's test, $r=0.096, R^{2}=0.009, p=0.806$ ).

Table 1. A summary of fish and hard coral diversity indices for each of the 9 study reefs in the central Saudi Arabian Red Sea (see Section 2.1 for abbreviations). For coral genus and fish species richness, the numbers shown are the maximum numbers of genera and species found on each reef, respectively. Fish species evenness was calculated 
from Shannon's Diversity Index for each reef which was based on the reported species richness. Each reef was surveyed using six replicate visual belt transects. Habitat indicates the location of each reef on the continental shelf, 261 Reef is the abbreviated name of each study reef.

\begin{tabular}{ccccc}
\hline Habitat & Reef & $\begin{array}{c}\text { Hard coral genus } \\
\text { richness }\end{array}$ & $\begin{array}{c}\text { Fish species } \\
\text { richness }\end{array}$ & $\begin{array}{c}\text { Fish species } \\
\text { evenness }\end{array}$ \\
\hline \multirow{5}{*}{ offshore } & RR & 14 & 60 & 0.68 \\
& NR & 16 & 59 & 0.76 \\
& AMR & 20 & 55 & 0.59 \\
\hline \multirow{5}{*}{ midshelf } & FR & 23 & 69 & 0.62 \\
& TWR & 18 & 70 & 0.66 \\
& AHR & 20 & 64 & 0.61 \\
\hline \multirow{5}{*}{ inshore } & ASR & 10 & 54 & 0.77 \\
& TR & 18 & 70 & 0.72 \\
& EFR & 20 & 55 & 0.59 \\
\hline
\end{tabular}

3.5. Fish and benthic assemblages on inshore reefs are clearly different from all other reefs.

A number of iterations were attempted to identify any significant differences in fish and benthic assemblages between the reefs and between the two depths at which the data were collected.

267 These analyses used fish biomass, fish densities, and benthic cover. Here, we present the most 268 significant results, while a more complete list of NMDS, ANOSIM, and SIMPER analyses and 269 their results can be found in supplementary material (Table S6). 


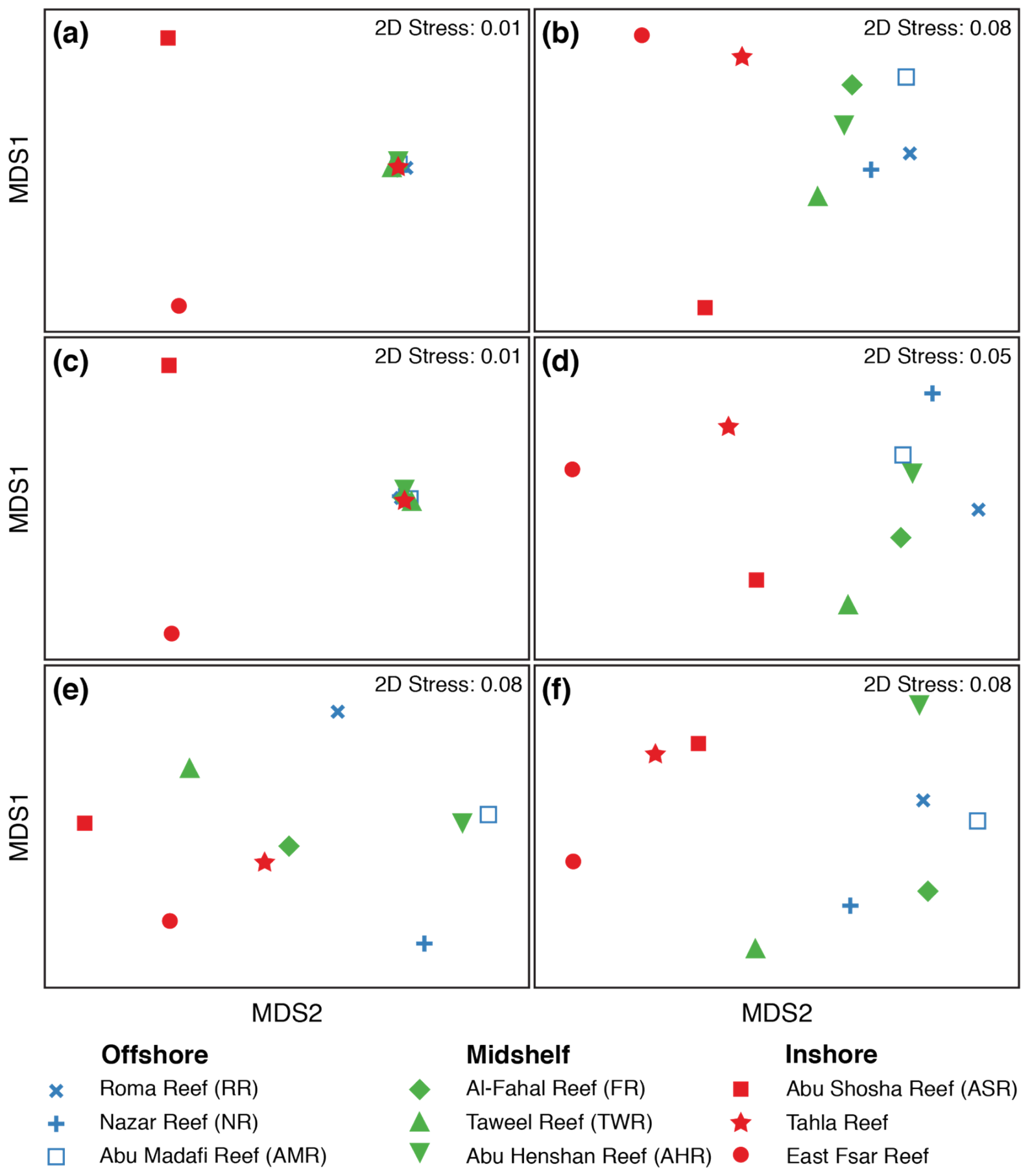

Figure 6. Non-metric multi-dimensional scaling (NMDS) plots from Bray-Curtis resemblance matrices based on log $(x+1)$-transformed reef averages for fish biomass ( $a$ and $b)$, fish densities ( $c$ and $d)$, and benthic cover (e and $f)$; the left column of panels shows $10 \mathrm{~m}$ assemblages, while the right column shows $2 \mathrm{~m}$ assemblages. X-axes represent NMDS1 and $y$-axes represent NMDS2. Reef name abbreviations are shown in the inset key next to their representative symbols, and the 9 reefs are color-coded according to distance from shore as shown by the key. 2D stress values are shown in the upper right corner of each plot. All data were averaged across the relevant replicates for each reef. Fish and benthic data were collected together on the same transects ( 6 per reef in total) from the central Saudi Arabian Red Sea. 
279

280

281

282

283

284

285

286

287

288

289

290

291

292

293

294

295

296

297

298

299

300

301

302

303

304

305

306

307

308

309

310

311

312

313

The NMDS plots for mean fish biomass and densities at $10 \mathrm{~m}$ (Figure $6 \mathrm{a}$ and $\mathrm{c}$ ) are very similar to each other with a very clear and tight clustering of all reefs in one cluster except for two inshore reefs (ASR and EFR), which separated from the other reefs but did not cluster closely together. This shows very high similarity (ANOSIM $R=0.9$, sig. 2.8) at $10 \mathrm{~m}$ depth in fish assemblages (by biomass as well as densities) among all reefs except ASR and EFR. In terms of biomass, Caesio lunaris (Family: Caesionidae) contributed the most to the dissimilarity (SIMPER dissimilarity contribution (hereafter Contrib.) $=7.9 \%$ ), being more abundant in the group containing offshore reefs, midshelf reefs, and one of the inshore reefs (TR).

However, looking at fish assemblages at $2 \mathrm{~m}$ (Figure $6 \mathrm{~b}$ and $\mathrm{d}$ ), we find all inshore reefs separating (including TR) from all other reefs, which clustered together (ANOSIM sig. 1.2\% for both biomass and densities). However, the offshore cluster was less tight than it was at $10 \mathrm{~m}$, indicating more dissimilarity within the shallow fish communities. The farming Stegastes nigricans contributed highly to the dissimilarity between inshore and offshore communities in terms of both biomass and numerical density (Contrib. 14.6 and $6.8 \%$, respectively), being abundant on inshore reefs and nearly absent on other reefs. Another damselfish, Chromis dimidiata, also contributed by being more abundant on midshelf and offshore reefs (Contrib. 4.3 \%).

As for benthic assemblages at $10 \mathrm{~m}$ (Figure $6 \mathrm{e}$ ), inshore reefs in addition to two midshelf reefs (TWR and FR) separated from the remaining four reefs (ANOSIM $R=0.78$, sig. $0.8 \%$ ), with sand and rubble (collective Contrib. $32.0 \%$ ) and CCA (9.2\%) contributing the most to the separation. Sand and rubble were more abundant in the group containing the inshore reefs, while CCA was more abundant in the group containing the offshore reefs. However, at $2 \mathrm{~m}$ (Figure 6 f), there was a clearer separation again between inshore reefs and all other reefs (ANOSIM $R=$ 0.82, sig. $1.8 \%$ ). Turf algae (Contrib. $14.6 \%$ ), rock (10.4\%), and Porites $(10.0 \%)$ were more abundant on inshore reefs, contributing highly to the dissimilarity, while Pocillopora (14.3\%), CCA (13.5\%), and xeniid soft corals $(9.6 \%)$ were more abundant on offshore and midshelf reefs (Table S6).

\section{Discussion}

We present here a description of the spatial variation in fish and benthic communities on a group of central Saudi Arabian Red Sea reefs, with particular focus on differences in assemblages along a cross-shelf gradient. Our results show that fish biomass increases moderately with distance from shore in Thuwal and that fish communities are dominated by herbivorous fishes at all sites. Benthic communities are fairly similar with the exception of shallow inshore sites. As very little detailed ecological data is available for this region, this study will be valuable for future Red Sea reef research and for conservation planning efforts. 


\subsection{Low fish biomass, absence of top predators, and low abundances of commercial} fishes suggest possible overfishing and low resilience.

It is likely that the increase in mean fish biomass with distance from shore, which was mostly evident at $10 \mathrm{~m}$ depth, is mostly due to the change in surrounding water depth (Figure 1). Inshore reefs slope to a sandy bottom at much shallower depths (between $12-20 \mathrm{~m}$ ) than the offshore reefs (Figure 1), and so offshore reefs may simply be able to support the occurrence of higher biomass than inshore reefs. In another part of the Red Sea, McMahon et al. (2016) found that offshore reefs had elevated contributions of planktonic carbon to their food webs compared to inshore reefs. It is possible this is further translated into increased productivity and fish biomass offshore. Our results showed that this increase in biomass could not be explained by coral cover or coral diversity.

Moreover, as a general trend, fish biomass on Thuwal reefs appears to be relatively low with particularly low proportions of top predators. Compared to relatively remote and nominally pristine locations around the world, including sites in the central Pacific (Sandin et al. 2008; Williams et al. 2011; Friedlander et al. 2014), the North-Western Hawaiian Islands (Friedlander and DeMartini 2002; Williams et al. 2011), and even some relatively remote and unfished parts of the Red Sea (Kattan 2014; Spaet et al. 2016), Thuwal reefs had very low fish biomass. Only Nazar Reef (NR) and Abu Madafi Reef (AMR), which had the highest mean biomass values in this study (Figure 3), had values comparable to, and sometimes higher than these sites (Table 2). However, even when mean biomass on NR exceeded that of other sites, it is important to note that the percentage of top predators in all other sites far exceeded NR's $39 \%$ (most of which was contributed by two whitetip reef sharks - the only sharks observed in our study). Herbivores make up the bulk of the biomass on Thuwal reefs (Figure 3).

Our survey design (using short belt transects and having a small number of replicates) might not be adequate for capturing the abundances of large mobile predators such as sharks, trevallies, and barracudas, which are typically surveyed using other techniques such as baited cameras (e.g., Robbins et al. 2005; Goetze and Fullwood 2013; Spaet et al. 2016). Nevertheless, we used the same method that was applied by Kattan (2014) in the Sudanese Red Sea, where much higher abundances of top predators were neverthelesss recorded. Some of the other studies listed in Table 2 also used a similar transect length (e.g., Sandin et al. 2008) and captured much higher abundances of top predators. Therefore, we believe that the absence of top predators in our study reflects true low abundances. 
Table 2. A comparison of mean fish biomass and top predator composition between Thuwal reefs and reefs considered pristine in studies in other regions. The comparison includes the mean biomass on Nazar reef as the reef with the highest mean biomass in this study as well as the overall mean biomass of all nine Thuwal reefs. Biomass indicates the mean fish biomass (standardized to $\mathrm{kg} / 100 \mathrm{~m}^{2}$ ) from each site, while top predator composition indicates the percentage of top predator biomass compared to total fish biomass. There were no major differences in the way in which top predators were defined across the studies.

\begin{tabular}{|c|c|c|c|c|}
\hline Site & Region & $\begin{array}{l}\text { Mean fish } \\
\text { biomass } \\
\left(\mathrm{kg} / 100 \mathrm{~m}^{2}\right)\end{array}$ & $\begin{array}{c}\text { Top predator } \\
\text { composition }(\%)\end{array}$ & Study \\
\hline Kingman Reef & Pacific & 53 & 81 & $\begin{array}{l}\text { Sandin et al. } \\
2008\end{array}$ \\
\hline $\begin{array}{l}\text { Pearl \& Hermes } \\
\text { Atoll }\end{array}$ & $\begin{array}{l}\text { North-Western Hawaiian } \\
\text { Islands }\end{array}$ & 47 & 81 & $\begin{array}{l}\text { Friedlander and } \\
\text { DeMartini } \\
2002\end{array}$ \\
\hline Kure Atoll & $\begin{array}{l}\text { North-Western Hawaiian } \\
\text { Islands }\end{array}$ & 35 & 66 & $\begin{array}{l}\text { Williams et al. } \\
2011\end{array}$ \\
\hline Jarvis Reef & Pacific & 25 & 68 & $\begin{array}{l}\text { Williams et al. } \\
2011\end{array}$ \\
\hline $\begin{array}{l}\text { French Frigate } \\
\text { Shoals }\end{array}$ & $\begin{array}{l}\text { North-Western Hawaiian } \\
\text { Islands }\end{array}$ & 26 & 62 & $\begin{array}{l}\text { Friedlander and } \\
\text { DeMartini } \\
2002\end{array}$ \\
\hline Palmyra Atoll & Pacific & 25 & 64 & $\begin{array}{l}\text { Sandin et al. } \\
2008\end{array}$ \\
\hline Ducie Island & Pacific & 16 & 63 & $\begin{array}{l}\text { Friedlander et } \\
\text { al. } 2014\end{array}$ \\
\hline Deep South & Red Sea, Sudan & 43 & 67 & Kattan (2014) \\
\hline Nazar Reef & Red Sea, Saudi Arabia & 31 & 39 & This study \\
\hline $\begin{array}{l}\text { All Thuwal } \\
\text { Reefs }\end{array}$ & Red Sea, Saudi Arabia & 16 & 13 & This study \\
\hline
\end{tabular}

353 Top predators such as sharks, jacks, and groupers are critical in maintaining the structure of reef 354 communities, and overfishing these groups can lead to trophic cascades and overall loss of 355 diversity and resilience (Friedlander and DeMartini 2002; Sandin et al. 2008; Salomon et al. 356 2010; Houk and Musburger 2013). Thus, the trophic structure on Thuwal reefs raises concerns 357 about resilience, which should be addressed in future studies, and points to a possible overfishing 358 problem. Currently, there is substantial and growing evidence of severe overfishing in the Saudi 
359

360

361

362

363

364

365

366

367

368

369

370

371

372

373

374

375

376

377

378

379

380

381

382

383

384

385

386

387

388

389

390

391

392

393

394

395

396

397

Arabian Red Sea. Decades of catch records suggest that Saudi Arabian fisheries may have been operating beyond sustainable levels since the 1990s (Jin et al. 2012). Similarly, Spaet and Berumen (2015) have shown evidence of unsustainable elasmobranch fisheries based on two years of fish market surveys. The trophic structure observed on Thuwal reefs in our study, therefore, could be a result of overfishing. Additionally, the absence of one of the major commercial species from our surveys, the grouper Plectropomus pessuliferus (Family: Serranidae), and the lack of significant variability in the biomass of the three commercial fish groups shown in Figure 4 also suggest heavy and spatially homogeneous fishing pressure. There is substantial evidence in the literature showing that protection from fishing can lead to relatively rapid recovery of stocks and to generally healthier reefs (e.g., Gell and Roberts. 2003; Bruce et al. 2012; Almany et al. 2013), and so, prompt action to stop overfishing in Saudi Arabia may lead to positive results.

Herbivores are also an essential functional group for maintaining the resilience of reefs, as they assist coral recruitment and recovery from disturbances by keeping macroalgae under control (Williams and Polunin 2001; Hughes et al. 2007; Ledlie et al. 2007). We speculate that the increase in herbivore biomass with increasing distance from shore in Thuwal indicates that offshore reefs may be relatively more resilient than inshore reefs. However, it is unknown whether the resilience of even the offshore reefs is adequate in the face of continuing overfishing.

\subsection{Variations in coral and algal cover show impacts of a bleaching event and indicate degradation of inshore habitat.}

Coral cover differed significantly between inshore reefs as a group and other reefs, which is likely partially due to the impact of the 2010 bleaching event (Furby et al. 2013; Pineda et al. 2013). It appears that these inshore reefs have not yet recovered their live coral cover in the $\sim 3$ years that passed between the bleaching event and the commencement of data collection for this study. (This situation is likely to continue as inshore reefs were again impacted by a similar bleaching event in 2015 (Lozano-Cortés et al. 2016).) Studies from other locations, such as the Great Barrier Reef, have similarly found that coral cover on inshore reefs tended to decline more severely than on offshore reefs following disturbances (e.g., Sweatman et al. 2007). However, recovery time was found to be highly variable; while some studies reported relatively rapid recovery of coral cover (e.g., 2.5 years reported by Hughes et al. (2007)), others reported that, even after six years, inshore reefs hardly recovered any lost coral cover (Sweatman et al. 2011).

At the same time, inshore reefs in this study have higher coverage of turf algae and high abundance of the damselfish species that farms it, Stegastes nigricans (Family: Pomacentridae), accompanied by generally lower herbivore biomass and diversity. The presence of $S$. nigricans and their turf algae farms has previously been found to be associated with high rates of coral mortality and high abundances of coral disease-associated pathogens, and they are often considered indicators of a degraded habitat (Casey et al. 2014; Casey et al. 2015; White and O'Donnell 2010). This potentially raises further concerns about the health of inshore reefs in 
398

399

400

401

402

403

404

405

406

407

408

409

410

411

412

413

414

415

416

417

418

419

420

421

422

423

424

425

426

427

428

429

430

431

432

433

434

435

436

Thuwal and their vulnerability to future disturbances. Larger datasets and continuous monitoring of the reefs would allow stronger inferences about future reef resilience in Thuwal (e.g., Bellwood et al. 2004; Pratchett et al. 2011).

\subsection{Correlations between benthic and fish diversity indices may not be observable due to compounding effects of stressors or to small sample size.}

Although previous studies have found benthic cover, diversity, and complexity to be correlated with fish species richness (e.g., Roberts and Ormond 1987; Chabanet et al. 1997; Chong-Seng et al. 2012), we found no such patterns on Thuwal reefs neither with coral cover nor with coral genus richness. This could be due to different stresses impacting reef communities simultaneously. For instance, if fishing pressure is impacting fish communities (and indirectly benthic communities) and the bleaching event has impacted the benthic communities (and indirectly the fish communities), then any naturally occurring correlations between benthic cover or diversity and fish diversity could become unobservable. Alternatively, the lack of correlation between benthic and fish diversity could be due to the number of replicates in the survey design, which may not be adequate for investigating such correlations. Although traditional survey methods such as LIT are commonly used to assess general coral cover, they have been shown to be less effective in assessing coral richness or diversity unless sampling effort is highly intensified (Leujak and Ormond 2007; Roberts et al. 2016). Finally, the relationship between benthic and fish diversity in Thuwal may be non-linear, thus requiring further analysis beyond linear correlation. Therefore, in this study, the relationship between fish and benthic diversity may be observable only in terms of qualitative assemblage rather than quantitative indices.

\subsection{Inshore fish and benthic assemblages are markedly different from offshore assemblages partially due to the impacts of coral bleaching.}

It appears that, especially in the shallower depths, inshore reefs are markedly different in fish and benthic assemblage from other reefs in the area. Furby et al. (2013) had found that, prior to bleaching, coral assemblages (genus-level abundances and coral cover) were similar on inshore and offshore Thuwal reefs, and that the post-bleaching differences were mostly caused by a decline in acroporids and pocilloporids on inshore reefs, which are faster-growing corals that tend to be more susceptible to bleaching (Marshall and Baird 2000). Very similar trends were also reported in other locations, for example in French Polynesia by Berumen and Pratchett (2006). Our study supports these findings and also shows turf algae to be one of the main contributors to the dissimilarity between inshore and offshore shallow communities. Similarly, we also found the slow-growing genus Porites to be a more characteristic community component on inshore reefs, while Acropora, Pocillopora, and Stylophora were important components distinguishing assemblages only on midshelf and offshore shallow communities.

Herbivore assemblages are commonly recognized as a key functional component of coral reef communities (Lewis 1986; Hughes et al. 2007; Adam et al. 2011). On Thuwal reefs, we found very similar herbivore assemblages on all reefs except the inshore reefs. Offshore communities were characterized by the surgeonfishes Acanthurus sohal, Naso unicornis, Ctenochaetus 
437

438

439

440

441

442

443

444

445

446

447

448

449

450

451

452

453

454

455

456

457

458

459

460

461

462

463

464

465

466

467

468

469

470

471

472

473

striatus, and A. nigrofuscus, while inshore communities were dominated mostly by the farming damselfish Stegastes nigricans. This coincides with the higher abundance of turf algae inshore and presents a potential difficulty for the recovery process of inshore reefs. These territorial damselfish promote the mono-cultural growth of algae on reef flats and crests, subsequently preventing settlement by corals and other invertebrates (e.g., White and O'Donnell 2010), whereas other types of grazers, such as surgeonfishes and parrotfishes, tend to remove algae and promote invertebrate settlement (Vine 1974; Jones et al. 2006). Thus, the low herbivore diversity on inshore reefs indicates potentially reduced resilience.

On our deeper transects, fish assemblages were very similar across all reefs except for two of the inshore reefs. With regards to both biomass and numerical density (Figure 6), the offshore communities seem to be dominated by planktivorous fishes, such as Caesio lunaris, Chromis dimidiata, Chromis flavaxilla, and Pseudanthias squamipinnis; these contributed the most to the similarity within the offshore reef cluster. We speculate that this trend may be due to a higher influx of zooplankton on more exposed reefs (e.g., Hamner et al. 1988).

It seems that, apart from the known bleaching event that altered inshore communities in 2010, Thuwal reef communities are fairly similar in structure. Repeating this study in an area of the Saudi Arabian Red Sea where bleaching did not occur may confirm or deny that the bleaching was the main driver of the differences we observed among reef communities. In the meantime, however, bleaching impact seems to be a highly likely variable. Inshore reefs are most likely vulnerable to thermal bleaching as a result of anomalous reductions in wind-driven circulation (Furby et al. 2013); the seascape arrangement may thus be among the most significant environmental drivers in this area. Our results suggest that inshore reefs may be generally less healthy and more vulnerable to disturbances than offshore reefs.

\section{Conclusions}

We presented a description of the spatial variation of fish biomass and fish and benthic communities on Thuwal reefs in the central Saudi Arabian Red Sea. Our findings can be summarized as follows:

1) Offshore Thuwal reefs seem to support higher fish biomass than inshore reefs. But fish biomass in Thuwal in general is quite low compared to other reef systems around the world and in the Red Sea that are considered "healthy" or relatively pristine.

2) Trophic structure on all Thuwal reefs is bottom-heavy with most biomass attributed to herbivores; top-predators are few or nearly absent.

3) Commercially valuable fish are in very low abundance throughout the area.

4) There are a few dissimilarities in benthic and fish assemblages which are mostly found between inshore reefs as a group and all other reefs:

a. Inshore benthic communities are characterized by having more turf algae and slow-growing corals compared to offshore reefs. 
474

475

476

477

478

479

480

481

482

483

484

485

486

487

488

489

490

491

492

493

494

495 b. Farming damselfish dominate shallow inshore herbivore communities compared to more diverse herbivore communities on offshore reefs.

In addition to identifying inshore areas in Thuwal to be more vulnerable to disturbances such as thermal stress, our findings support existing evidence that Thuwal reefs may be heavily overfished, as indicated by trophic structure and low biomass (Sections 4.1 and 4.2). Intense fishing affects communities on many levels, from species' life-history traits to population fitness and community structure, in ways that generally lower diversity and reef resilience (Robertson et al. 2005; Salomon et al. 2010). The status of both sharks (Spaet et al. 2012; Spaet and Berumen 2015) and groupers (DesRosiers 2011) are particularly alarming in the Saudi Arabian Red Sea, even compared to other parts of the Red Sea (Kattan 2014; Spaet et al. 2016), and fishing regulations as well as other forms of protection may be urgently needed to halt the collapse of fisheries.

Collectively, these findings provide preliminary scientific basis for future spatial prioritization and conservation planning in Thuwal. Our results also identify individual species that characterize inshore and offshore reefs, and these species, together with a selection of commercial species, could now be used to set quantitative conservation objectives (e.g.. Schmiing et al. 2014). The results presented here thus enable future resource management, conservation efforts, and spatial planning to be based on data, as opposed to convenience or "best-guesses" of appropriate actions.

\section{Acknowledgements}

Fieldwork was facilitated by the KAUST Coastal and Marine Research Core Lab, and Tane Sinclair-Taylor provided assistance with creating one of the figures. 
496 References

497 Adam TC, Schmitt RJ, Holbrook SJ, Brooks AJ, Edmunds PJ, Carpenter RC, Bernardi G (2011) Herbivory, connectivity, and ecosystem resilience: response of a coral reef to a large-scale perturbation. PLoS One 6:e23717

Almany Glenn R, Hamilton Richard J, Bode M, Matawai M, Potuku T, Saenz-Agudelo P, Planes S, Berumen Michael L, Rhodes Kevin L, Thorrold Simon R, Russ Garry R, Jones Geoffrey P (2013) Dispersal of grouper larvae drives local resource sharing in a coral reef fishery. Current Biology : CB 23:626-630

Alwany MA, Stachowitsch M (2007) Distribution and diversity of six common reef fish families along the Egyptian coast of the Red Sea. Journal of Fisheries and Aquatic Science 2:1-16

Arrigoni R, Berumen ML, Terraneo TI, Caragnano A, Bouwmeester J, Benzoni F (2014) Forgotten in the taxonomic literature: resurrection of the scleractinian coral genus Sclerophyllia (Scleractinia, Lobophylliidae) from the Arabian Peninsula and its phylogenetic relationships. Systematics and Biodiversity 13:140-163

Balmford A, Green MJB, Murray MG (1996) Using Higher-Taxon Richness as a Surrogate for Species Richness: I. Regional Tests. Proceedings of the Royal Society B 263:1267-1274

Beenaerts N, Berghe EV (2005) Comparative study of three transect methods to assess coral cover, richness and diversity. Western Indian Ocean Journal of Marine Science 4:29-37

Bellwood DR, Hughes TP, Folke C, Nyström M (2004) Confronting the coral reef crisis. Nature 429:827-833

Berumen M, Pratchett M (2006) Recovery without resilience: persistent disturbance and long-term shifts in the structure of fish and coral communities at Tiahura Reef, Moorea. Coral Reefs 25:647-653

Berumen ML, Hoey AS, Bass WH, Bouwmeester J, Catania D, Cochran JEM, Khalil MT, Miyake S, Mughal MR, Spaet JLY, Saenz-Agudelo P (2013) The status of coral reef ecology research in the Red Sea. Coral Reefs 32:737-748

Bett BJ, Narayanaswamy BE (2014) Genera as proxies for species $\alpha$ - and $\beta$-diversity: tested across a deep-water Atlantic-Arctic boundary. Marine Ecology 35:436-444

Bouchon-Navaro Y, Bouchon C (1989) Correlations between chaetodontid fishes and coral communities of the Gulf of Aqaba (Red Sea). In: Motta P (ed) The butterflyfishes: success on the coral reef. Springer Netherlands, pp47-60

Bouwmeester J, Benzoni F, Baird AH, Berumen ML (2015) Cyphastrea kausti sp. n. (Cnidaria, Anthozoa, Scleractinia), a new species of reef coral from the Red Sea. ZooKeys:1-13

Bruce T, Meirelles PM, Garcia G, Paranhos R, Rezende CE, de Moura RL, Filho R-F, Coni EOC, Vasconcelos AT, Amado Filho G, Hatay M, Schmieder R, Edwards R, Dinsdale E, Thompson FL (2012) Abrolhos bank reef health evaluated by means of water quality, microbial diversity, benthic cover, and fish biomass data. PloS One 7:e36687

Casey JM, Ainsworth TD, Choat JH, Connolly SR (2014) Farming behaviour of reef fishes increases the prevalence of coral disease associated microbes and black band disease. Proceedings of the Royal Society B: Biological Sciences 281

Casey JM, Connolly SR, Ainsworth TD (2015) Coral transplantation triggers shift in microbiome and promotion of coral disease associated potential pathogens. Scientific Reports 5:11903

Chabanet P, Ralambondrainy H, Amanieu M, Faure G, Galzin R (1997) Relationships between coral reef substrata and fish. Coral Reefs 16:93-102

Chong-Seng KM, Mannering TD, Pratchett MS, Bellwood DR, Graham NAJ (2012) The influence of coral reef benthic condition on associated fish assemblages. Plos One 7(8): e42167

Clarke K, Gorley R (2006) PRIMER: User manual/tutorial. PRIMER-E, Plymouth

Clarke KR (1993) Non-parametric multivariate analyses of changes in community structure. Australian Journal of Ecology 18:117-143

Davis KA, Lentz SJ, Pineda J, Farrar JT, Starczak VR, Churchill JH (2011) Observations of the thermal environment on Red Sea platform reefs: a heat budget analysis. Coral Reefs 30:25-36

DesRosiers N (2011) Growth and maturation of Plectropomus spp. in the Saudi Arabian Red Sea. Master of Science Thesis. King Abdullah University of Science and Technology, Saudi Arabia 
545

546

547

548

549

550

551

552

553

554

555

556

557

558

559

560

561

562

563

564

565

566

567

568

569

570

571

572

573

574

575

576

577

578

579

580

581

582

583

584

585

586

587

588

589

590

591

592

593

594

DeVantier L, Turak E, Al-Shaikh K, De'ath G (2000) Coral communities of the central-northern Saudi Arabian Red Sea. Fauna of Arabia 18:23-66

Fabricius KE (2005) Effects of terrestrial runoff on the ecology of corals and coral reefs: review and synthesis. Marine Pollution Bulletin 50:125-146

Friedlander AM, DeMartini EE (2002) Contrasts in density, size, and biomass of reef fishes between the northwestern and the main Hawaiian islands: the effects of fishing down apex predators. Marine Ecology Progress Series 230:253-264

Friedlander AM, Caselle JE, Ballesteros E, Brown EK, Turchik A, Sala E (2014) The real bounty: Marine biodiversity in the Pitcairn Islands. Plos One 9:e100142

Froese R, Pauly D (2014) FishBase. World Wide Web electronic publication. www.fishbase.org

Furby KA, Bouwmeester J, Berumen ML (2013) Susceptibility of central Red Sea corals during a major bleaching event. Coral Reefs 32:505-513

Game ET, McDonald-Madden EVE, Puotinen ML, Possingham HP (2008) Should we protect the strong or the weak? Risk, resilience, and the selection of marine protected areas. Conservation Biology 22:1619-1629

Gell FR, Roberts CM (2003) Benefits beyond boundaries: the fishery effects of marine reserves. Trends in Ecology \& Evolution 18:448-455

Goetze JS, Fullwood LAF (2013) Fiji’s largest marine reserve benefits reef sharks. Coral Reefs 32:121-125

Hamner WM, Jones MS, Carleton JH, Hauri IR, Williams DM (1988) Zooplankton, Planktivorous fish, and water currents on a windward reef face: Great Barrier Reef, Australia. Bulletin of Marine Science 42:459-479

Heip CHR, Herman PMJ, Soetaert K (1998) Indices of diversity and evenness. Océanis 24:61-87

Houk P, Musburger C (2013) Trophic interactions and ecological stability across coral reefs in the Marshall Islands. Marine Ecology Progress Series 488:23-34

Huang D, Benzoni F, Arrigoni R, Baird AH, Berumen ML, Bouwmeester J, Chou LM, Fukami H, Licuanan WY, Lovell ER, Meier R, Todd PA, Budd AF (2014) Towards a phylogenetic classification of reef corals: the Indo-Pacific genera Merulina, Goniastrea and Scapophyllia (Scleractinia, Merulinidae). Zoologica Scripta 43:531-548

Hughes TP, Rodrigues MJ, Bellwood DR, Ceccarelli D, Hoegh-Guldberg O, McCook L, Moltschaniwskyj N, Pratchett MS, Steneck RS, Willis B (2007) Phase shifts, herbivory, and the resilience of coral reefs to climate change. Current Biology 17:360-365

Jessen C, Lizcano JFV, Bayer T, Roder C, Aranda M, Wild C, Voolstra CR (2013) In-situ effects of eutrophication and overfishing on physiology and bacterial diversity of the Red Sea coral Acropora hemprichii. PloS One 8:e62091

Jin D, Kite-Powell HL, Hoagland P, Solow AR (2012) A bioeconomic analysis of traditional fisheries in the Red Sea off the coast of the Kingdom of Saudi Arabia. Marine Resource Economics 27:137-148

Jones GP, Santana L, McCook LJ (2006) Resource use and impact of three herbivorous damselfishes on coral reef communities. Marine Ecology Progress Series 328:215-224

Kattan A (2014) Baselines and comparison of Red Sea fish assemblages in the central Red Sea. Master of Science Thesis. King Abdullah University of Science and Technology, Saudi Arabia

Khalil M (2015) Designing local-scale marine protected area networks in the central Saudi Arabian Red Sea. PhD Thesis. King Abdullah University of Science and Technology. Thuwal, Saudi Arabia

Khalil M, Cochran JM, Berumen M (2013) The abundance of herbivorous fish on an inshore Red Sea reef following a mass coral bleaching event. Environmental Biology of Fishes 96:1065-1072

Ledlie MH, Graham NAJ, Bythell JC, Wilson SK, Jennings S, Polunin NVC, Hardcastle J (2007) Phase shifts and the role of herbivory in the resilience of coral reefs. Coral Reefs 26:641-653

Leujak W, Ormond RFG (2007) Comparative accuracy and efficiency of six coral community survey methods. Journal of Experimental Marine Biology and Ecology 351:168-187

Lewis SM (1986) The role of herbivorous fishes in the organization of a Caribbean reef community. Ecological Monographs 56:183-200

Lozano-Cortés D, Robitzch V, Abdulkader K, Kattan Y, Elyas A, Berumen M (2016) Coral bleaching in Saudi Arabia affecting both the Red Sea and Arabian Gulf. Reef Encounter 31:50-51 
595

596

597

598

599

600

601

602

603

604

605

606

607

608

609

610

611

612

613

614

615

616

617

618

619

620

621

622

623

624

625

626

627

628

629

630

631

632

633

634

635

636

637

638

639

640

641

642

643

644

Malcolm H, Jordan A, Smith SA (2010) Biogeographical and cross-shelf patterns of reef fish assemblages in a transition zone. Marine Biodiversity 40:181-193

Margules CR, Pressey RL (2000) Systematic conservation planning. Nature 405:243-253

Marshall PA, Baird AH (2000) Bleaching of corals on the Great Barrier Reef: differential susceptibilities among taxa. Coral Reefs 19:155-163

McMahon, KW, SR Thorrold, LA Houghton, ML Berumen (2016) Tracing carbon through coral reef food webs using a compound-specific stable isotope approach. Oecologia 180: 809-821

Mervis J (2009) The big gamble in the Saudi desert. Science 326:354-357

Nemeth M, Appeldoorn R (2009) The distribution of herbivorous coral reef fishes within fore-reef habitats: the role of depth, light and rugosity. Caribbean Journal of Science 45:247-253

PERSGA/GEF (2003) Coral reefs in the Red Sea and Gulf of Aden: Surveys 1990 to 2000 Summary and recommendations. PERSGA Technical Series No 7. PERSGA, Jeddah

Pratchett M, Trapon M, Berumen M, Chong-Seng K (2011) Recent disturbances augment community shifts in coral assemblages in Moorea, French Polynesia. Coral Reefs 30:183-193

Price ARG, Jobbins G, Shepherd ARD, Ormond RFG (1998) An integrated environmental assessment of the Red Sea coast of Saudi Arabia. Environmental Conservation 25:65-76

Roberts CM, Alexander RDS, Ormond RFG (1992) Large-scale variation in assemblage structure of Red Sea butterflyfishes and angelfishes. Journal of Biogeography 19:239-250

Roberts MB, Jones GP, McCormick MI, Munday PL, Neale S, Thorrold S, Robitzch VSN, Berumen ML (2016) Homogeneity of coral reef communities across 8 degrees of latitude in the Saudi Arabian Red Sea. Marine Pollution Bulletin 105:558-565

Roberts TE, Bridge TC, Caley MJ, Baird AH (2016) The point count transect method for estimates of biodiversity on coral reefs: Improving the sampling of rare species. Plos One 11:e0152335

Robertson DR, Choat JH, Posada JM, Pitt J, Ackerman JD (2005) Ocean surgeonfish Acanthurus bahianus. II. Fishing effects on longevity, size and abundance? Marine Ecology Progress Series 295:245-256

Robbins WD, Hisano M, Connolly SR, Choat JH (2006) Ongoing collapse of coral-reef shark populations. Current Biology 16:2314-2319

Salomon AK, Gaichas SK, Shears NT, Smith JE, Madin EMP, Gaines SD (2010) Key features and contextdependence of fishery-induced trophic cascades. Conservation Biology 24:382-394

Sandin SA, Smith JE, DeMartini EE, Dinsdale EA, Donner SD, Friedlander AM, Konotchick T, Malay M, Maragos JE, Obura D, Pantos O, Paulay G, Richie M, Rohwer F, Schroeder RE, Walsh S, Jackson JBC, Knowlton N, Sala E (2008) Baselines and degradation of coral reefs in the Northern Line Islands. PLoS ONE 3:e1548

Schmiing M, Diogo H, Serrão Santos R, Afonso P (2014) Marine conservation of multispecies and multi-use areas with various conservation objectives and targets. ICES Journal of Marine Science: Journal du Conseil 72 (3): 851-862

Sheppard C, Price A, Roberts C (1992) Marine ecology of the Arabian region: Patterns and processes in extreme tropical environments. Academic Press Ltd., London, England, Uk; San Diego, California, USA

Spaet JLY, Berumen ML (2015) Fish market surveys indicate unsustainable elasmobranch fisheries in the Saudi Arabian Red Sea. Fisheries Research 161:356-364

Spaet JL, Nanninga GB, Berumen ML (2016) Ongoing decline of shark populations in the eastern Red Sea. Biological Conservation 201:20-28

Spaet JLY, Thorrold SR, Berumen ML (2012) A review of elasmobranch research in the Red Sea. Journal of Fish Biology 80:952-965

Sweatman H, Delean S, Syms C (2011) Assessing loss of coral cover on Australia's Great Barrier Reef over two decades, with implications for longer-term trends. Coral Reefs 30:521-531

Sweatman H, Thompson A, Delean S, Davidson J, Neale S (2007) Status of near-shore reefs of the Great Barrier Reef 2004. MTSRF Report No 2. Reef and Rainforest Research Centre, 169 p.

Terraneo, TI; Berumen, ML; Arrigoni, R; Waheed, Z; Bouwmeester, J; Caragnano, A; Stefani, F; Benzoni, F (2014) Pachyseris inattesa sp. n. (Cnidaria, Anthozoa, Scleractinia): a new reef coral species from the Red Sea and its phylogenetic relationships. ZooKeys 433: 1-30 
645 Tornabene L, Ahmadia GN, Berumen ML, Smith DJ, Jompa J, Pezold F (2013) Evolution of microhabitat

646

647

648

649

650

651

652

653

654

655

656

657

658

659 association and morphology in a diverse group of cryptobenthic coral reef fishes (Teleostei: Gobiidae: Eviota). Molecular Phylogenetics and Evolution 66:391-400

van der Merwe R, Röthig T, Voolstra CR, Ochsenkühn MA, Lattemann S, Amy GL (2014) High salinity tolerance of the Red Sea coral Fungia granulosa under desalination concentrate discharge conditions: An in situ photophysiology experiment. Frontiers in Marine Science 1, doi: 10.3389/fmars.2014.00058

Vine PJ (1974) Effects of algal grazing and aggressive behaviour of the fishes Pomacentrus lividus and Acanthurus sohal on coral-reef ecology. Marine Biology 24:131-136

White J-SS, O'Donnell JL (2010) Indirect effects of a key ecosystem engineer alter survival and growth of foundation coral species. Ecology 91:3538-3548

Williams ID, Richards BL, Sandin SA, Baum JK, Schroeder RE, Nadon MO, Zgliczynski B, Craig P, McIlwain JL, Brainard RE (2011) Differences in reef fish assemblages between populated and remote reefs spanning multiple archipelagos across the central and western Pacific. Journal of Marine Biology 2011:14

Williams IW, Polunin NP (2001) Large-scale associations between macroalgal cover and grazer biomass on middepth reefs in the Caribbean. Coral Reefs 19:358-366 